Na jaki temat będzie książka, nad którą Ojciec ostatnio pracuje?

Jej tytuł roboczy to słowa świętego Pawła do Tymoteusza: „Strzeż depozytu”. Podtytuł będzie pewnie brzmiał: „Wołanie Nowego Testamentu o prawowierność". Na tle tego, co się dzieje w teologii Zachodu uważałem za stosowne przypomnieć przede wszystkim tym, którzy zajmują się wykładem wiary, jak dalece Nowy Testament kładzie nacisk na to, żeby się trzymać „zdrowej nauki”, jak to powtarzają wielokrotnie listy pasterskie świętego Pawła. Poradziłem się paru księży biskupów - potwierdzili słuszność moich zapatrywań. Napisałem do Ojca świętego - tak samo zaaprobował prosząc, żebym mu przesłał program mojej książki. Dotąd jest tego niewiele - kilkadziesiąt stronic, praca idzie powoli. Jestem jednak przekonany, że będzie to coś zupełnie nowego, a jednocześnie na pewno opartego na słowie Bożym.

Oczekujemy więc na ukazanie się Ojca książki i dziękujemy za rozmowę.

Rozmawiata Iwona Haberny.

Rozmowa wyemitowana zostala 14 maja 1996 roku w Radiu Mariackim Kraków.

\title{
KALENDARIUM BIOGRAFICZNE O. AUGUSTYNA JANKOWSKIEGO OSB
}

1916 - 14. IX. ur. w mieście Złatoust na Uralu, $2 \mathrm{~km}$ od granicy z Azją jako drugi syn Franciszka Jankowskiego, inżyniera metalurga i Modesty z Andrzejewskich (starszy brat Arnold, ur. 1915, zmarł we wczesnym dzieciństwie ok. 1917 r.). Ochrzczony imieniem Bogdan tamże w kościele rzymsko-katolickim św. App. Piotra i Pawła (Złatoust jako węzłowa stacja kolei transsyberyjskiej był obsadzony Polakami, którzy zatroszczyli się o wybudowanie murowanej świątyni).

1917 - Wyjazd na Syberię - ojciec walczył w V Dywizji Syberyjskiej (korpus gen. Hallera) pod dow. Płka Czumy (późniejszego dowódcy obrony Warszawy w 1939 r.), dostal się do niewoli - przebywal w Gródku k. Krasnojarska.

1921 - Powrót rodziny do Polski na zasadzie wymiany jeńców po traktacie ryskim z ZSRR. Granice przekroczyli repatrianci w listopadzie w wagonach bydlęcych $(O$. Jankowski pamięta częściowo to wydarzenie - na stacji granicznej Stołpce zaśpiewal „Jeszcze 
Polska nie zginęla" - jego ojciec, bardzo muzykalny, choć stwierdził ten dowód patriotyzmu dziecka, uznal śpiew za fałszywy). Po odbyciu kwarantanny w Dęblinie (obawa o tyfus) rodzina osiedliła się w Toruniu, gdzie ojciec dostał posadę w zakładach amunicyjnych (w stopniu porucznika, potem awansowany na kapitana).

1923 - Rozpoczęcie nauki w Szkole Podstawowej, tzw. ćwiczeniówce przy żeńskim seminarium nauczycielskim (przyjęty od razu do kl. II).

1926 - I Komunia św. w kaplicy tamże.

We wrześniu rozpoczęcie nauki w gimnazjum Mikołaja Kopernika (dziś akademickie - od Henryka Strohbanda, burmistrza z XVII w., który ufundował szkołę jako rodzaj akademii - historię szkoły badał jeden z jej uczniów, prof. Zbigniew Zdrójkowski).

1927 - 26. VI - bierzmowanie $w$ katedrze św. Jana $w$ Toruniu $z$ rąk ówczesnego biskupa chełmińskiego Stanisława Wojciecha Okoniewskiego: otrzymał imię Jerzy.

1929 - Ojciec dostał posadę w Skarżysku-Kamiennej, ale Bogdan z matką pozostał w Toruniu, by kontynuować naukę w dobrym gimnazjum. Początki powołania w czasie wakacji, kiedy był ministrantem w par. Bzin (dziś Skarżysko II). Przedtem myślał o takich zawodach jak astronom, historyk i chemik. Podczas wakacji roku 1933 Bogdan zaliczył obóz junaków (przysposobienie wojskowe) w Solcu Kujawskim.

1934 - Matura w Toruniu i rozpoczęcie studiów filozoficznych na Uniwersytecie Warszawskim (ojciec dostal prace $w$ Warszawie w 1933 r., rodzina przeniosła się tam w lipcu 1934 r.). Pragnął zaraz po maturze rozpocząć studia teologiczne, ale wobec kategorycznego protestu rodziców, którzy domagali się, by przedtem odbył studia świeckie, wybrał filozofię jako najbardziej zbliżoną do teologii. W 1935 r. dodał do niej filologię klasyczną. Uczestniczył $\mathrm{w}$ interdyscyplinarnym seminarium prowadzonym przez profesorów A. Krokiewicza i Jana Łukasiewicza (logika). Słuchał m.in. wykładów profesorów: Tadeusza Kotarbińskiego, Władysława Tatarkiewicza, Wladysława Witwickiego a na filologii: Adama Krokiewicza, Kazimierza Kumanieckiego, Aleksandra Turyna, Tadeusza Zielińskiego. Podczas studiów stykal się m.in. z takimi w przyszłości znanymi osobami jak Jan Kott, Alfred Laszowski, Bolesław Miciński, Lidia Winniczuk, Czesław Łanowski. Należał do Sodalicji Mariańskiej Akademików, najpierw był jej prezesem na UW, a potem prefektem całej warszawskiej międzyuczelnianej sodalicji akademickiej. Uczestniczył w akademickiej pielgrzymce do Częstochowy w 1936 r. podczas której składano ślubowanie (trzymał wstążkę od wotum, złotego ryngrafu, podczas procesji na wałach).

1937 - Smierć ojca (w wieku lat 57).

1938 - Dyplom magisterski z filozofii - praca pisana pod kierunkiem prof. W. Tatarkiewicza pt. O poznaniu empirycznym u Arystotelesa ze szczególnym uwzględnieniem pojęcia faktu oraz zagadnienia czy poznanie empiryczne zawiera pierwiastki nieempiryczne. Pielgrzymka do Rzymu na kanonizację św. Andrzeja Boboli. 
1939 - Dyplom z filologii klasycznej - praca pisana pod kierunkiem prof. Adama Krokiewicza Aristoteles quid de inductione senserit.

We wrześniu rozpoczęcie studiów teologicznych w seminarium duchownym Archidiecezji Warszawskiej. Zastanawiał się, czy nie wstąpić od razu do zakonu, ale przyjął radę doświadczonych kapłanów, że stosunkowo łatwo można przejść z diecezji do zakonu, natomiast $\mathrm{z}$ zakonu do diecezji jest to droga niezaszczytna. Podczas bombardowania Warszawy, gdy 20. IX. 1939 r. bomba niemiecka zabiła 7 kolegów, złożył ślub, że gdy będzie miał warunki moralne (ciążył na nim obowiązek utrzymywania matki oraz ciotki, swojej matki chrzestnej), wstąpi do zakonu o ślubach uroczystych.

Od 29. IX po zbombardowaniu seminarium alumni przebywali w katolickim domu Roma. Przełożeni zostali aresztowani, domem zarządzał ojciec duchowny ks. P. Dembiński CM. Jeden z kolegów $\mathrm{w}$ obawie przed rewizją wyrzucił przez okno magazynek $\mathrm{z}$ nabojami karabinowymi. Zauważył to żołnierz niemiecki - przeprowadzono rewizję w seminarium. Pod łóżkiem alumna Jankowskiego zwrócono uwage na walizkę. Na jej wierzchu był polikopiowany skrypt z liturgiki - po przejrzeniu go niemiecki oficer już nie badał zawartości walizki. Udało się wyjść z tej trudnej sytuacji, o której ks. Dembiński mówił, że był to najcięższy dzień w jego życiu.

4. X. wszyscy alumni zostali aresztowani, przewiezieni na $\mathrm{Pa}$ wiak do opróżnionego oddziału żeńskiego zwanego "Serbią". Alumna Jankowskiego zwolniono $\mathrm{z}$ wieloma księżmi po 11 dniach.

Największy wpływ na duchowość alumna wywarł ojciec duchowny ks. Paweł Dembiński CM. Spośród profesorów szczególnie wspomina ks. E. Dąbrowskiego, dogmatyków: ks. Wl. Rosłana i ks. Antoniego Pawłowskiego (potem biskupa włocławskiego, u którego pisał pracę magisterską o Eucharystii u św. Ignacego z Antiochii - Instytut Biblijny wymagał wtedy stopnia $\mathrm{z}$ dogmatyki). Potem praca licencjacka z Rzymu B. Jankowskiego została uznana przez UW za doktorską - 1948).

1942 - Śmierć Matki (12. VIII).

1943 - 19. VI - święcenia kapłańskie z rąk abpa Antoniego Szlagowskiego (wikariusza kapitulnego w Warszawie z uprawnieniami ordynariusza, byłego rektora UW i profesora homiletyki i patrologii). Praca w parafii Kołbiel od 11. VII. 43 do 11. III. 1945 (20 miesięcy).

1945 - Od 15. III praca w seminarium jako prefekt i profesor. Seminarium mieściło się w majątku Czubin k. Błonia (par. Rokitno).

1946 - 24. X. wyjazd na studia do Rzymu do Biblicum. Promotorem pracy ks. Bogdana Jankowskiego był o. Urban Holzmeister SI (Austriak), bardzo podobały mu się wykłady o. St. Lyonneta SI, słuchał też o. A. Bea SI, o. L. Semkowskiego SI, (hebraisty, który wtedy pełnil też funkcję rektora Kolegium przy Piazza Remuria opuszczonego przez Zmartwychwstańców), ochrzczonego rabina Eugenio Zolli (nawróconego m.in. pod wpływem podziwu dla 
działalności Piusa XII, pochodził ze Złoczowa, rodzinnej miejscowości bpa W. Świerzawskiego, mówił po polsku z akcentem lwowskim, w Polsce nosil nazwisko Zoll) o. O'Callagana - (prof. geografii biblijnej, jego bratanek wykładał później krytykę tekstu), Alberto Vaccariego. W tym czasie studiowali na Biblicum m.in. X. Léon-Dufour, J. Dupont, Heinz Kruse, Peter Nober (redagował Index Bibliographicus do „Biblica”), John McKenzie SI, o. R. North SI, J.T. Milik, Bronisław Zieliński SI (potem profesor wielu szkół jezuickich), Walter Kornfeld (potem prof. we Wiedniu).

1947 - Blisko 4 miesiące wakacji spędza u przyjaciela, rektora domu józefinów w Thiene (rodzinnym mieście św. Kajetana, diec. Vicenza).

1948 - Praca licencjacka pod kierunkiem o. Urbana Holzmeistra SI, Schola historiae formarum quid de resuscitationibus evangelicis sentiat, exponitur et examinatur (Druk: CT 21 (1949), s. 77 106.219-258), 18. VI. - przysięga antymodernistyczna po końcowych egzaminach uprawniająca do wykładów.

14. VII. - powrót do Polski, praca w seminarium. Rada Wydziału Teologicznego UW uznaje pracę z Biblicum za spełniającą wymagania do doktoratu $\mathrm{z}$ apologetyki (prom. Ks. Wincenty Kwiatkowski, promocja w grudniu 1948). Praca apostolska: wicemoderator sodalicji akademiczek, jeden z duszpasterzy akademickich przy kościele św. Anny (do 1955 r.).

1952 - Habilitacja na podstawie pracy Znak spod Nain (druk CT 32(1962), s. 5-180) na UW - ponens: Ks. prof. Seweryn Kowalski, recenzenci: Ks. prof. W. Kwiatkowski, Ks. prof. Paweł Nowicki (pismo przyznające tytuł docenta w zakresie Studium Nowego Testamentu nosi date z grudnia 1952).

1953 - Śmierć ciotki - matki chrzestnej Teodory Andrzejewskiej (31. I), rozpoczęcie starań o pozwolenie na wstąpienie do klasztoru.

1955 - 7. IX przyjazd do Tyńca, postulat.

29. XI - rozpoczęcie nowicjatu kanonicznego, nadanie imienia Augustyn.

1956 - 3O. XI - pierwsze śluby zakonne.

1958 - Na sympozjum biblistów w Seminarium Częstochowskim w Krakowie podjęto przygotowania do polskiego przekładu Biblii z języków oryginalnych na wzór Biblii Jerozolimskiej - późniejszej Biblii Tysiąclecia.

1959 - 30. XI. - uroczyste śluby zakonne.

Wykłady zlecone na KUL.

Od ok., Wykłady w Seminarium Krakowskim (jako magister aggregatus 1963 - - odpowiednik docenta - teologia biblijna, potem egzegeza Nowego Testamentu).

1964 - Nominacja na profesora nadzwyczajnego.

1971 - Pierwszy doktorat - o. Ludwik Mycielski OSB, następne: Tomasz Jelonek (1974), ks. Stanisław Chłąd (1980), o. Tomasz M. Dąbek OSB (1982), o. Roman Zdziarstek OP (1984) S. Boguchwała Kuras OSU (1984). 
64

1973 - Nominacja na profesora zwyczajnego.

1978 - Powołanie do Papieskiej Komisji Biblijnej (nominacja podpisana przez Pawła VI, uczestnictwo w jej pracy podczas dwóch pięcioletnich kadencji - do 1989 r.).

1982 - Wiosna: udział w Kongresie Pneumatologów w Rzymie i pielgrzymka do Ziemi Swiętej.

1985 - 26. II. wybór na Opata w Tyńcu (do 27. II. 1993),

31. III. uroczyste błogosławieństwo (Niedziela Palmowa - ks. Kard. F. Macharski) Udział w kapitułach generalnych kongregacji: 1980 (Glenstal - Irlandia), 1988 (Singeverga - Portugalia), 1992 (Trewir - Niemcy).

Udział w rzymskich kongresach opatów: 1984, 1988, 1992.

1996 - 7. XII nadanie tytułu doktora honoris causa Wydziału Teologii Papieskiej Akademii Teologicznej w Krakowie w 600-lecie istnienia Wydziału i w 15-lecie powołania pierwszej w Polsce Papieskiej Akademii Teologicznej.

Opr. benedyktyni tynieccy

\author{
PRACE O. PROFESORA \\ DRA HAB. AUGUSTYNA JANKOWSKIEGO \\ PUBLIKOWANE NA ŁAMACH \\ RUCHU BIBLIJNEGO I LITURGICZNEGO
}

\title{
A R T Y K U L Y
}

1. Aktualność apokaliptycznych listów do siedmiu Kościołów (Ap 2 i 3). 3(1959) 260-277

2. Biblijne pojęcie świętości człowieka. 2(1984) 109-118

3. Codzienne spotkanie z żywym Słowem Bożym. 4(1958) 335-342 182

4. Doniosłość Łukaszowej eschatologii indywidualnej. 4-5(1975) 168-

5. Duch a Jezus. 1(1983) 16-21

6. Dwojakie orędzie eschatologiczne ( Łk 6, 6-26; 1 Kor 7, 25-31). Homilia. 4-6(1991) 129-130

7. Elementy teologii męczeństwa w Liście do Filipian. 3(1962) 160-166

8. Eucharystia jako „Nowa Pascha” (1 Kor 5,7) w teologii biblijnej Nowego Testamentu. 3(1975) 89-100

9. Homilie wielkopostne na rok A. 1(1972) 48-61

10. Horyzonty kosmiczne odkupienia w teologii biblijnej. 1(1966) 23-44

11. Idea wyzwolenia w listach św. Pawła. 2(1987) 110-119

12. Mater Ecclesiae. 4(1965) 183-205 